\title{
Analysing the modified Hoek-Brown failure criteria using Hungarian granitic rocks
}

\author{
Balázs Vásárhelyi • László Kovács • Ákos Török
}

Received: 20 July 2015/Accepted: 15 December 2015/Published online: 22 January 2016

(C) Springer International Publishing Switzerland 2016

\begin{abstract}
The Hoek-Brown empirical failure envelope is widely used for determining the strength of brittle intact rock and rock masses. One of the two independent parameters in the formula is the HoekBrown's material constant $\left(\mathrm{m}_{\mathrm{i}}\right)$, which has several uncertainties, since it relies on a set of triaxial tests. The present paper introduces a new approach to determine the material constant by using the uniaxial compressive strength, rather than the triaxial strength values. This newly calculated Hoek-Brown parameter was cross-checked by using published data and new experimental data obtained from granitic samples of Bátaapáti (Hungary). Based on these new equations new material constants are suggested to be used in calculations.
\end{abstract}

Keywords Hoek-Brown failure criterion - Uniaxial compressive strength · Geological Strength Index ·

Granitic rock

B. Vásárhelyi $(\bowtie)$ · Á. Török

Department of Engineering Geology and Geotechnics,

Budapest University of Technology and Economics,

Budapest, Hungary

e-mail: vasarhelyib@gmail.com

Á. Török

e-mail: torokakos@mail.bme.hu

L. Kovács

RockStudy Ltd, Pecs, Hungary

e-mail: kovacslaszlo@komero.hu

\section{Introduction}

The Hoek-Brown (HB) failure criterion is widely used in rock mass characterization of tunnels (e.g. Zhao 2000; Deák et al. 2013), road cuts and cliff face stability analyses (e.g. Lindsay et al. 2001). It was developed to characterize the behaviour of rock mass by using laboratory strength parameters and material constants. The criterion was introduced by Hoek and Brown (1980) and the following form is used for intact rock:

$\sigma_{1}=\sigma_{3}+\sigma_{c i}\left(m_{i} \frac{\sigma_{3}}{\sigma_{c i}}+1\right)^{0.5}$

where $\sigma_{1}$ : the major principal stress at failure, $\sigma_{3}$ : the minor principal stress or confining pressure, $\mathrm{m}_{\mathrm{i}}$ : Hoek-Brown material constant, $\sigma_{\mathrm{ci}}$ : the uniaxial compressive strength of the intact rock.

According to Eq. (1), two independent parameters are necessary, namely the:

- uniaxial compressive strength $\left(\sigma_{\mathrm{ci}}\right)$, and the

- Hoek-Brown material constant of the intact rock $\left(\mathrm{m}_{\mathrm{i}}\right)$

Hoek and Brown (1997) suggested that these values should be determined by numerous triaxial tests (minimum five sets of test), applying different confining pressures $\left(\sigma_{3}\right)$ between 0 and $0.5 \times \sigma_{\mathrm{ci}}$. These laboratory tests are time consuming, expensive and in many cases there are not enough (or suitable) samples 
to obtain the necessary amount of data. Hoek (2007) provided values of $\mathrm{m}_{\mathrm{i}}$ constants for different types of rocks. The values of $\mathrm{m}_{\mathrm{i}}$ are in between 7 and 35 , however several factors influence these values. Mineral composition, grain size and cementation are among others that control the $\mathrm{m}_{\mathrm{i}}$ (Table 1).

Nevertheless, the detremination of the exact $m_{i}$ value is very important for the rock engineering design, due to the sensitivity of the Hoek-Brown equations (Ván and Vásárhelyi 2014). Shen and Karakus (2014) also emphasized the difficulties in determining the $m_{\mathrm{i}}$ values of rocks. They suggested to normalize the Hoek-Brown constant $\left(m_{\mathrm{i}}\right)$ by using strength of the rock $\left(\sigma_{\mathrm{ci}}\right)$. The modified version of the Hoek-Brown Eq. (1) is as follows: $\sigma_{1}=\sigma_{3}+\sigma_{c i}\left(m_{i n} \sigma_{3}+1\right)^{0.5}$

where $m_{\mathrm{in}}=m_{\mathrm{i}} / \sigma_{\mathrm{ci}}$.

In their paper the Hoek-Brown parameter $\left(\mathrm{m}_{\mathrm{i}}\right)$ as the function of the uniaxial strength of the rock $\left(\sigma_{\mathrm{ci}}\right)$ (Fig. 1a) was illustrated. The strength dependence of the normalized Hoek-Brown constant $\left(\mathrm{m}_{\mathrm{in}}\right)$ (Fig. 1b) were also calculated rock types.

By analyzing the data of five different rock types they found a correlation between the normalized material constant $\left(\mathrm{m}_{\mathrm{in}}\right)$ and the uniaxial compressive strength of the rocks $\left(\sigma_{\mathrm{ci}}\right)$. The $\mathrm{m}_{\mathrm{i}}$ value of limestone was found to be in between 7 and 14. By fitting a regression curve, According to Shen and Karakus (2014) the Eq. (3) can be used to estimate $m_{\text {in }}$ values

Table 1 Suggested values of the Hoek-Brown constant ' $\mathrm{m}_{\mathrm{i}}$ ' for intact rock (Hoek 2007) (values in parenthesis are estimates)

\begin{tabular}{|c|c|c|c|c|c|c|}
\hline \multirow[t]{2}{*}{ Rock type } & \multirow[t]{2}{*}{ Class } & \multirow[t]{2}{*}{ Group } & \multicolumn{4}{|l|}{ Texture } \\
\hline & & & Coarse & Medium & Fine & Very fine \\
\hline \multirow[t]{4}{*}{ Sedimentary } & Clastic & & $\begin{array}{l}\text { Conglomerates* } \\
\quad(21 \pm 3) \\
\text { Breccias }(19 \pm 5)\end{array}$ & Sandstones $17 \pm 4$ & $\begin{array}{l}\text { Siltstones } 7 \pm 2 \\
\text { Greywackes } \\
\quad(18 \pm 3)\end{array}$ & $\begin{array}{l}\text { Clay stones } \\
7 \pm 2 \\
\text { Shales } \\
\quad(6 \pm 2) \\
\text { Marls }(7 \pm 2)\end{array}$ \\
\hline & $\begin{array}{l}\text { Non- } \\
\text { Clastic }\end{array}$ & Carbonates & $\begin{array}{l}\text { Crystalline limestone } \\
\quad(12 \pm 3)\end{array}$ & $\begin{array}{l}\text { Sparitic limestones } \\
\quad(10 \pm 2)\end{array}$ & $\begin{array}{l}\text { Micritic limestones } \\
\quad(9 \pm 2)\end{array}$ & $\begin{array}{l}\text { Dolomites } \\
\quad(9 \pm 3)\end{array}$ \\
\hline & & Evaporites & & Gypsum $8 \pm 2$ & Anhydrite $20 \pm 2$ & \\
\hline & & Organic & & & & Chalk $7 \pm 2$ \\
\hline \multirow[t]{3}{*}{ Metamorphic } & Non foliated & & Marble $9 \pm 3$ & $\begin{array}{l}\text { Hornfels }(19 \pm 4) \\
\text { Metasandstone } \\
\quad(19 \pm 3)\end{array}$ & Quartzites $20 \pm 3$ & \\
\hline & $\begin{array}{l}\text { Slightly } \\
\text { foliated }\end{array}$ & $\begin{array}{l}\text { Mismatite } \\
\quad(29 \pm 3)\end{array}$ & Amphibolites $26 \pm 6$ & & & \\
\hline & Foliated** & $\begin{array}{l}\text { Gneiss } \\
28 \pm 5\end{array}$ & Schists $12 \pm 3$ & Phyllites (7 \pm 3 ) & Slates $7 \pm 4$ & \\
\hline \multirow[t]{6}{*}{ Igneous } & Plutonic & Light & $\begin{array}{l}\text { Granite } 32 \pm 3 \\
\text { Granodiorite }(29 \pm 3)\end{array}$ & Diorite $25 \pm 5$ & & \\
\hline & & Dark & $\begin{array}{l}\text { Gabbro } 27 \pm 3 \\
\text { Norite } 20 \pm 5\end{array}$ & Dolerite $(16 \pm 5)$ & & \\
\hline & Hypabyssal & & Porphyries $(20 \pm 5)$ & & Diabase $(15 \pm 5)$ & $\begin{array}{l}\text { Peridotite } \\
\qquad(25 \pm 5)\end{array}$ \\
\hline & Volcanic & Lava & & Rhyolite $(25 \pm 5)$ & Dacite $(25 \pm 3)$ & $\begin{array}{l}\text { Obsidian } \\
\qquad(19 \pm 3)\end{array}$ \\
\hline & & & & Andesite $25 \pm 5$ & Basalt $(25 \pm 5)$ & \\
\hline & & Pyroclastic & Agglomerate $(19 \pm 3)$ & Breccia $(19 \pm 5)$ & Tuff $(13 \pm 5)$ & \\
\hline
\end{tabular}


Fig. 1 a Relations between $m_{\mathrm{i}}$ and $\sigma_{\mathrm{ci}} ; \mathbf{b}$ relations between $\mathrm{m}_{\mathrm{in}}$ and $\sigma_{\mathrm{ci}}$ both for limestone (Shen and Karakus 2014)
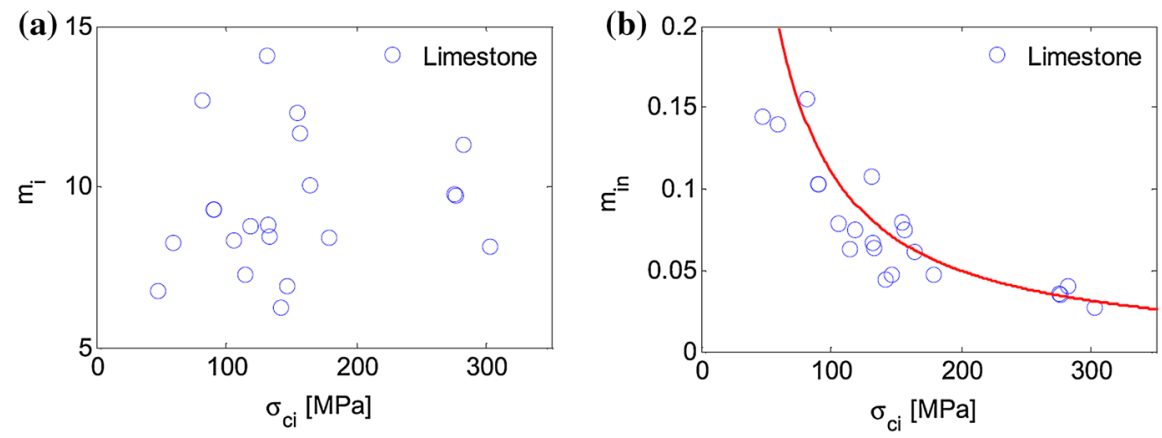

from uniaxial compressive strength $\left(\sigma_{\mathrm{ci}}\right)$ values for different rock types:

$m_{\text {in }}=A \sigma_{c i}^{B}$

where $A$ and $B$ are the material parameters, of various rock types (Table 2).

\section{Analyzing existing suggested methods for Hoek- Brown constant}

Sheorey (1997) collected and published 187 independent triaxial test results and calculated the HoekBrown parameter $\left(\mathrm{m}_{\mathrm{i}}\right)$ of intact rocks. By using this data set and calculating with Eq. (3) a strong relationship between the normalized Hoek-Brown constant $\left(\mathrm{m}_{\mathrm{i}}\right)$ and the uniaxial compressive strength of the rock $\left(\sigma_{\mathrm{ci}}\right)$ was found (Fig. 2).

According to these results, a new equation can be formulated:

$m_{\text {in }}=10.94 \sigma_{c i}^{-0.998} \approx 10 \sigma_{c i}^{-1}$

It is well known, that when the Brinke number $\left(R=\sigma_{\mathrm{c}} /\left|\sigma_{\mathrm{t}}\right|\right)$ is higher than 8 , the $R$-value is equal to Hoek-Brown constant, i.e. equals to $m_{\mathrm{i}}$ (Cai 2010):

Table 2 The modified Hoek-Brown parameters ( $A$ and $B$ ) by Shen and Karakus (2014)

\begin{tabular}{lrl}
\hline Type of rock & $A$ & $B$ \\
\hline Coal & 120 & -1.70 \\
Granite & 100 & -1.20 \\
Limestone & 22 & -1.15 \\
Marble & 100 & -1.55 \\
Sandstone & 50 & -1.26 \\
\hline
\end{tabular}

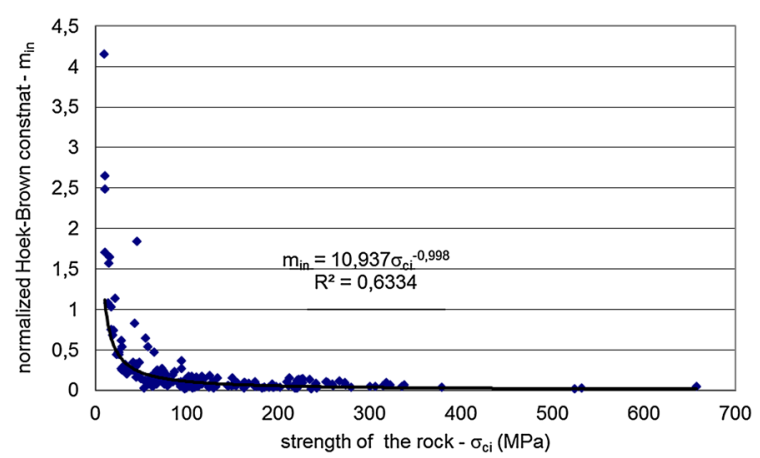

Fig. 2 Normalized Hoek-Brown parameter as a function of uniaxial compressive strength-data from Sheorey (1997)

$m_{i} \approx \frac{\sigma_{c}}{\left|\sigma_{t}\right|}=R$

Statistically, the Brinke number is around 10 (Andreev 1995).

The $A$ and $B$ values given by Shen and Karakus (2014) (cf. Eq. 3) were also recalculated for different rock types, using the data set published by Sheorey (1997) (Table 3).

This equation (Eq. 3) was also used to evaluate the data set of Hungarian granitic rocks of Bátaapáti site

Table 3 The calculated modified Hoek-Brown parameters, data from Sheorey (1997)

\begin{tabular}{llll}
\hline Type of rock & No of data & $A$ & $B$ \\
\hline Coal & 24 & 160 & -1.80 \\
Limestone (crystalline) & 11 & 62 & -1.47 \\
Limestone & 22 & 2.75 & -0.64 \\
Quartzite & 10 & 2.49 & -1.23 \\
Slate & 20 & 18.29 & -1.23 \\
Sandstone & 49 & 43 & -1.27 \\
\hline
\end{tabular}


(Hungary). A radioactive waste repository (for L/LW) was designed and had been built during the past 10 years with a tunnel system of more than $6 \mathrm{~km}$ in length at that site. The engineering geology and rock engineering behaviour of this area was described by Deák et al. (2014).

The design of the tunnel systems was based mainly on the Hoek-Brown theory, which included the determination of Hoek-Brown constants of different granitic rock types. Multiple Failure State tests have been used, according to the ISRM method (Kovári et al. 1983). 44 samples were tested representing three slightly different lithologies: monzonitic (15), monzogranitic (14) and hybrid (contaminated monzonite and monzogranite) (15) rocks. All the samples were tested under air-dry conditions. The data was presented by Vásárhelyi et al. (2013). For triaxial tests right circular cylinders were prepared (according to ISRM, Kovári et al. 1983) with diameter of $38 \mathrm{~mm}$, and with height to diameter ratio of $2: 1$. No direct relationship was found between the Hoek-Brown constant $\left(m_{\mathrm{i}}\right)$ and the uniaxial strength of the rock $\left(\sigma_{\mathrm{ci}}\right)$
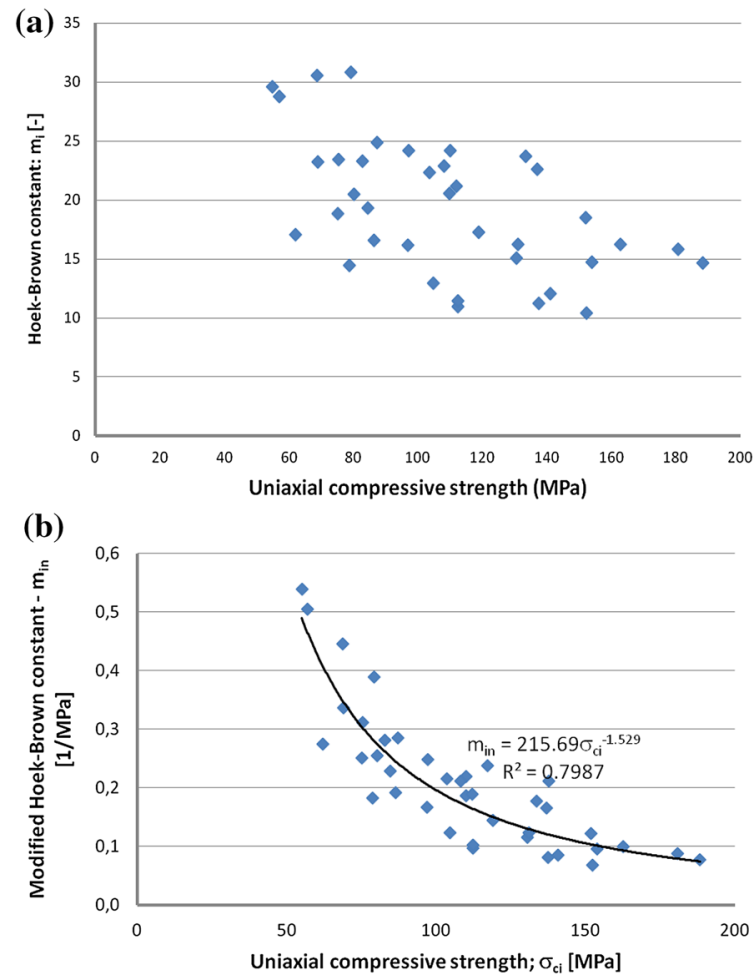

Fig. 3 a Relations between $m_{i}$ and $\sigma_{\text {ci }}$; b relations between $m_{\text {in }}$ and $\sigma_{\mathrm{ci}}$ for granitic rocks of Bátaapáti (Hungary)
(Fig. 3a). However, when the normalized HoekBrown constants are plotted against the uniaxial compressive strength a good correlation was recorded (Fig. 3b). It is in good agreement with the findings of Shen and Karakus (2014). $A$ and $B$ values were also calculated for each tested lithotypes according to Eq. 3 (Table 4).

\section{Correlation between the constants}

The correlation between $A$ and $B$ constants (according to Eq. 3) was also studied. Using all calculated and published data (Sheorey 1997; Shen and Karakus 2014; Vásárhelyi et al. 2013), the following relationship was found (Fig. 4):

$B=-0.212 \ln (A)-0.468\left(R^{2}=0.763\right)$

Plotting the data set of measured 44 granitic samples (Fig. 5) and applying the same formula for granitic rocks of Bátaapáti (Hungary), the following equation was found:

Table 4 The modified Hoek-Brown parameters of the granitic rocks from Bátaapáti

\begin{tabular}{lrr}
\hline Type of rock & $A$ & \multicolumn{1}{l}{$B$} \\
\hline Monzonite & 120 & -1.40 \\
Monzogranite & 87 & -1.14 \\
Hybrid (contaminated monzonite and & 387 & -1.67 \\
$\quad$ monzogranite) & & \\
Average value & 216 & -1.53 \\
\hline
\end{tabular}

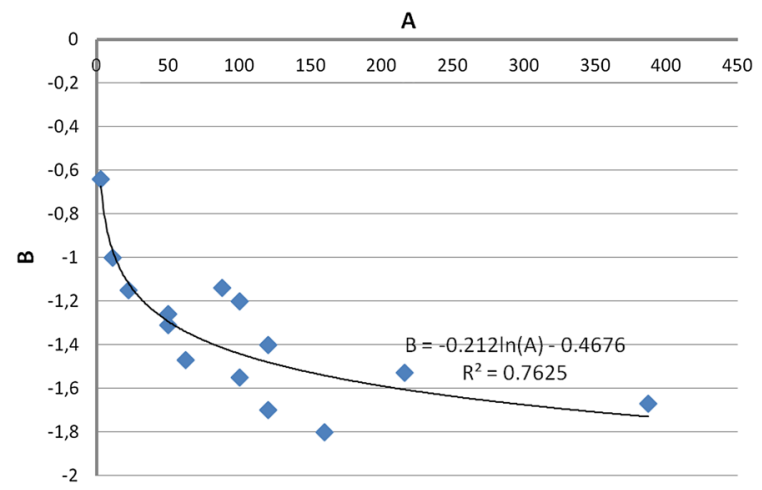

Fig. 4 Relations between A and B constants using published and calculated data (data from: Sheorey 1997; Shen and Karakus 2014; Vásárhelyi et al. 2013) 


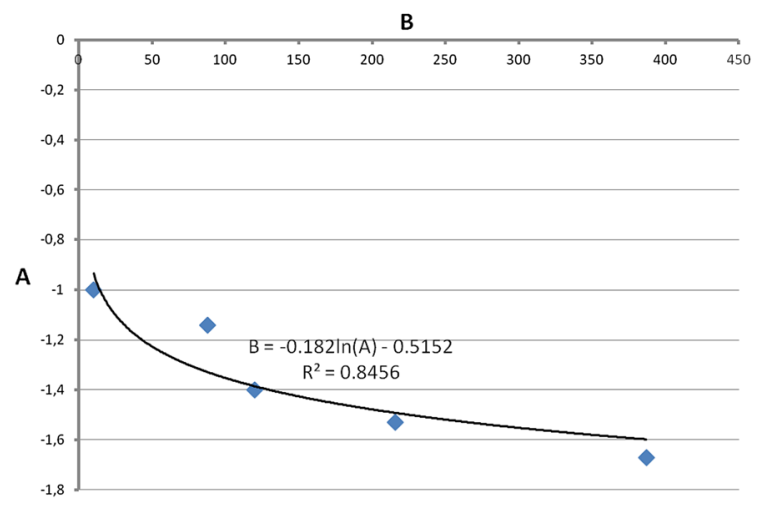

Fig. 5 Relations between A and B constants; granitic rocks from Bátaapáti (Hungary)

$B=-0.182 \ln (A)-0.515\left(R^{2}=0.848\right)$

The above listed equations provide a good estimation of rock mass strength of various lithologies and can be used for quick calculations when limited amount of laboratory results are available.

\section{Applying the theory for rock mass}

According to Hoek et al. (2002), the Hoek-Brown equation for rock mass is:

$\sigma_{1}=\sigma_{3}+\sigma_{c i}\left(m_{b} \frac{\sigma_{3}}{\sigma_{c i}}+s\right)^{a}$

where $m_{\mathrm{b}}$, s and $a$ Hoek-Brown parameters depend on both the Geological Strength Index (GSI) and the damage factor $(D)$. Both $s$ and $a$ parameters are independent of the $\mathrm{m}_{\mathrm{i}}$ value, thus the original formula can be used. For determining the Hoek-Brown parameter $m_{\mathrm{b}}$, originally the following form has been used:

$m_{b}=m_{i} \exp \left(\frac{G S I-100}{28-14 D}\right)$

According to Shen and Karakus (2014), this equation can be rewritten in the following form, using Eq. (3)

$m_{b}=A \sigma_{c i}^{B+1} \exp \left(\frac{G S I-100}{28-14 D}\right)$ where $G S I$ (Geological Strength Index) and $D$ (damage value) following the definition of Hoek et al. (2002).

Accordingly, the Hoek-Brown equation for rock mass can be modified applying the theory of Shen and Karakus (2014), using Eqs. (8) and (10):

$\sigma_{1}=\sigma_{3}+\sigma_{c i}\left(A \sigma_{c i}^{B} \sigma_{3}+s\right)^{a}$

Using the Eq. (11) the following relationship can be calculated for the granitic rocks of Bátaapáti:

$\sigma_{1}=\sigma_{3}+\sigma_{c i}\left(216 \sigma_{c i}^{-1.53} \sigma_{3}+s\right)^{a}$

\section{Conclusions}

The modified Hoek-Brown failure envelope (Shen and Karakus 2014) was recalculated by using the data set published by Sheorey (1997). New material constants are suggested for coal, limestone, quartzite, slate and sandstone. For the tested 44 granitic samples of Bátaapáti (Hungary), representing three lithotypes the application of the modified Hoek-Brown failure envelope proved to be more reliable than the classical one. It was shown that by using this method the failure envelope can be determined more exactly. A logarithmic correlation between the empirical constants ( $A$ and $B$ ) was also found, which strongly suggest that the assumption that these constants were independent could not be confirmed. It was also denoted that the failure envelope of the intact rock can be determined more exactly with the help of the new suggested equation. It also should be noted that the values of $\mathrm{A}$ and B depend on various factors including rock state, rock types, and specimen geometry.

\section{References}

Andreev GE (1995) Brittle failure of rock materials. Balkema, Rotterdam, p 446

Cai M (2010) Practical estimates of tensile strength and HoekBrown strength parameter mi of brittle rocks. Rock Mech Rock Eng 43:167-184

Deák F, Kovács L, Vásárhelyi B (2013) Modeling the excavation damage zones in the Bátaapáti radioactive waste repository. Rock mechanics for resources, energy and environment. Eurock 2013:603-608 
Deák F, Kovács L, Vásárhelyi B (2014) Geotechnical rock mass documentation in the Bátaapáti radioactive waste repository. Central Eur Geol 57(2):197-211

Hoek E (2007): Practical rock engineering-chapter 11: Rock mass properties. http://www.rocscience.com/hoek/corner/ 11_Rock_mass_properties.pdf

Hoek E, Brown ET (1980) Underground excavation in rock. Institution of Mining and Metallurgy, London, p 527

Hoek E, Brown ET (1997) Practical estimates of rock mass strength. Int J Rock Mech Min Sci 34(8):1165-1186

Hoek E, Carranza-Torres C, Corkum B (2002): Hoek-Brown failure criterion-2002 edition. In: Proceedings of the North American rock mechanics symposium, Toronto, pp $1-6$

Kovári K, Tisa A, Einstein HH, Franklin JA (1983) Suggested methods for determining the strength of rock materials in triaxial compression: revised version. Int J Rock Mech Min Sci Geomech Abstr 20(6):283-290
Lindsay P, Campbell RN, Fergusson DA, Gillard GR, Moore TA (2001) Slope stability probability classification, Waikato Coal Measures, New Zealand. Int J Coal Geol 45(2-3):127-145

Shen J, Karakus M (2014) Simplified method for estimating the Hoek-Brown constant for intact rocks. J Geotech Geoenviron Eng 140(1):04014025-1

Sheorey PR (1997) Empirical rock failure critera. Balkema, Rotterdam

Ván P, Vásárhelyi B (2014) Sensitivity analysis of GSI based mechanical parameters of the rock mass. Period Polytech Ser Civil Eng 58(4):379-386

Vásárhelyi B, Kovács L, Kovács B (2013) Determining the failure envelope of the intact granitic rocks from Bátaapáti. Geosci Eng 2(4):93-101

Zhao J (2000) Applicability of Mohr-Coulomb and HoekBrown strength criteria to the dynamic strength of brittle rock. Int J Rock Mech Min Sci 37(7):1115-1121 